\title{
Advances in Theoretical and Computational Energy Optimization Processes
}

\author{
Ferdinando Salata $*$ and Iacopo Golasi $*$ (1) \\ Department of Astronautics, Electrical and Energetics Engineering, University of Rome "Sapienza", \\ 00184 Rome, Italy \\ * Correspondence: ferdinando.salata@uniroma1.it (F.S.); iacopo.golasi@uniroma1.it (I.G.)
}

Received: 1 June 2020; Accepted: 1 June 2020; Published: 4 June 2020

check for updates

Industry, construction and transport are the three sectors that traditionally lead to the highest energy requirements. This is why, over the past few years, all the involved stakeholders have widely expressed the necessity to introduce a new approach to the analysis and management of those energy processes characterizing the aforementioned sectors. The objective is to guide production and energy processes to an approach aimed at energy savings and a decrease in environmental impact. Indeed, all of the ecosystems are stressed by obsolete production schemes deriving from an unsustainable paradigm of constant growth and related to the hypothesis of an environment able to absorb and accept all of the anthropogenic changes.

Leading the production processes of industry, construction and transport to a revision of their energy requirements is necessary and the research activity is called to carry out its natural innovative function.

The industrial sector is in full transition and transformation towards its version 4.0 and is therefore called to review its management and the supply costs of energy and raw materials to limit its environmental impact. Research activity must support best practices in energy management and encourage a reduction in greenhouse gas emissions. The construction sector should apply future retrofit solutions, able to increase energy efficiency and taking into account environment and climate change at the same time. The transport sector is moving towards new mobility with respect to the past, thanks to the transition from fossil fuels to the electrification and the use of artificial intelligence, thus increasing the level of automation. In the context of great attention towards the sustainable and respectful future of the planet, this study and the diffusion of the results provided by the scientific community concerning the most recent signs of progress in energy optimization are expected to play a key role.

With the aim of proposing the next generation of energy processes and leading to positive implications for the environment, climate and sustainability, this Special Issue, "Advances in Theoretical and Computational Energy Optimization Processes" has aimed to collect sophisticated contributions on all these aspects, highlighting current state-of-the-art research with respect to the results of the main research groups. Studies on energy processes, production methods and innovative mechanisms related to research based on computational optimization methods are part of this scientific collection. This Special Issue has also aimed to encourage a debate on future scenarios in each of those sectors currently characterized by significant energy requirements.

In this Special Issue, numerous articles have found a home and they have been proposed by researchers from countries belonging to geographical areas over the world. In particular, the affiliation of the authors sees nations represented according to the following percentages: China, 69\%; Pakistan, 9\%; Malaysia, 5\%; Mexico, 3\%; USA, 3\%; Spain, 2\%; Iran, Taiwan and Vietnam, 1.5\%; Norway and UK, $1 \%$; Chile, Denmark, Ghana, Oman and South Africa, $0.5 \%$. The topics covered range across all energy sectors. Starting from the production of energy up to its final consumption, the authors discuss 
and propose ideas and opportunities to optimize processes, methods, equipment and machinery to minimize energy needs from non-renewable sources and the environmental pollution derived from it.

The authors, in presenting their scientific works, have shown that it is possible to intervene in multiple sectors to try and optimize numerous energy processes. This is proof that the scientific community is active in producing ideas that will allow a transition to a low-carbon future and apply new theories and models based on innovative algorithms.

In particular, in the field of studies concerning energy optimization in the civil construction sector, the following publications have found space in this collection of scientific works:

- Smart Community Energy Cost Optimization Taking User Comfort Level and Renewable Energy Consumption Rate into Consideration (Keywords: smart communities; user comfort levels; renewable energy consumption rate) [1].

- Cogeneration Process Technical Viability for an Apartment Building: Case Study in Mexico (Keywords: cogeneration; technical viability; apartment building) [2].

- Efficient Energy Management in Offices Using Bio-Inspired Energy Optimization Algorithms (Keywords: appliance scheduling techniques; bacterial foraging algorithm (BFA); energy management; system; energy optimization algorithms; grasshopper optimization algorithm (GOA); smart grid) [3].

- Multi-Objective Optimal Scheduling Method for a Grid-Connected Redundant Residential Microgrid (Keywords: redundant residential microgrid (RR-microgrid); optimal scheduling; virtual energy storage system (VESS); non-dominant sorting genetic algorithm II (NSGA-II); analytic hierarchy process (AHP)) [4].

- Optimized Energy Management Strategies for Campus Hybrid PV-Diesel Systems During Utility Load Shedding Events (Keywords: hybrid PV-diesel generator systems; digital resource management; energy management) [5].

- A Modular Framework for Optimal Load Scheduling Under Price-Based Demand Response Scheme in Smart Grid (Keywords: smart grid; demand response; load scheduling; home energy management; enhanced differential evolution; hybrid gray wolf-modified enhanced differential evolutionary algorithm) [6].

The application of innovative methodologies to encourage more efficient transport has led to the production of the following scientific works:

- Hybrid Energy Feature Extraction Approach for Ship-Radiated Noise Based on CEEMDAN Combined with Energy Difference and Energy Entropy Complete Ensemble Empirical Mode Decomposition with Adaptive Noise (CEEMDAN) (Keywords: energy difference (ED); energy entropy (EE); hybrid energy feature extraction; ship-radiated noise (S-RN)) [7].

- Energy-Efficient Train Driving Strategy with Considering the Steep Downhill Segment (Keywords: rail transit; train control; energy-efficient driving strategy; steep downhill segment; local optimization) [8].

- Numerical Investigation of SCR Mixer Design Optimization for Improved Performance (Keywords: selective catalyst reduction system; emission control; marine diesel engine; urea; ammonia) [9].

- A Rotor-Sync Signal-Based Control System of a Doubly-Fed Induction Generator in the Shaft Generation of a Ship (Keywords: shaft generator; DFIG; shipboard; power; control) [10].

- Intelligent Energy Management for Plug-In Hybrid Electric Bus with Limited State Space (Keywords: plug-in hybrid electric bus; energy management; Q-learning; limited state space; Hardware-in-Loop (HIL) simulation) [11].

The research sector that operates in the production, transport and dispatching of energy has been enriched by the considerations contained in the following articles:

- Integrated Delphi-AHP and Fuzzy TOPSIS Approach Toward Ranking and Selection of Renewable Energy Resources in Pakistan (Keywords: Delphi; analytical hierarchy process; fuzzy technique 
for order of preference by similarity to ideal solution techniques; renewable energy (RE) resources; sustainable energy planning) [12].

- Flexible Responsive Load Economic Model for Industrial Demands (Keywords: demand-side management; economic demand response model; consumer utility function; electricity market restructuring) [13].

- Implementation of Maximum Power Point Tracking Based on Variable Speed Forecasting for Wind Energy Systems (Keywords: maximum power tracking (MPT); wind speed forecasting; wind energy system (WES); state feedback controller) [14].

- Numerical Investigation of Influence of Reservoir Heterogeneity on Electricity Generation Performance of Enhanced Geothermal System (Keywords: reservoir heterogeneity; enhanced geothermal system; electricity generation; performance; influence) [15].

- Modeling of Future Electricity Generation and Emissions Assessment for Pakistan (Keywords: electricity demand; emissions; LEAP model; fossil fuels; renewable energy) [16].

- Power Transmission Congestion Management Based on Quasi-Dynamic Thermal Rating (Keywords: transmission line; meteorological parameter; quasi-dynamic thermal rating (QDR); transmission congestion) [17].

- Control Strategy of Electric Heating Loads for Reducing Power Shortage in Power Grid (Keywords: power shortage; electric heating load; electric water heater; demand response; virtual energy storage (VES), virtual state of charge (VSOC)) [18].

- Productivity Models of Infill Complex Structural Wells in Mixed Well Patterns (Keywords: complex structural well; mixed well pattern; productivity evaluation; semi-analytical model; well location optimization) [19].

- Influence and Optimization of Geometrical Parameters on Coast-Down Characteristics of Nuclear Reactor Coolant Pumps (Keywords: reactor coolant pump; coast-down characteristics; geometrical parameters; multiple linear regression; transition process) [20].

- Model for Optimizing Location Selection for Biomass Energy Power Plants (Keywords: biomass energy; site selection; optimization; MCDM; FMCDM; FAHP; TOPSIS) [21].

- Wind Energy Generation Assessment at Specific Sites in a Peninsula in Malaysia Based on Reliability Indices (Keywords: reliability indices; wind farms; sequential Monte Carlo simulation; Malaysia) [22].

- Temporal Feature Selection for Multi-Step Ahead Reheater Temperature Prediction (Keywords: reheat steam temperature; temporal feature selection; delay order prediction; deep neural network; genetic algorithm) [23].

- Investigating the Dynamic Impact of $\mathrm{CO}_{2}$ Emissions and Economic Growth on Renewable Energy Production: Evidence from FMOLS and DOLS Tests (Keywords: carbon emissions; economic growth; energy; renewable energy; fully modified ordinary least square (FMOLS); dynamic panel cointegration model) [24].

- Mathematical Modeling and Simulation on the Stimulation Interactions in Coalbed Methane Thermal Recovery (Keywords: coalbed methane thermal recovery; thermal stimulation interaction; heat-gas-coal model; modeling and simulation) [25].

- Economic Dispatch of Multi-Energy System Considering Load Replaceability (Keywords: multi-energy system; economic dispatch; load replaceability; multi-energy conversion) [26].

- Using Pso Algorithm to Compensate Power Loss Due to the Aeroelastic Effect of the Wind Turbine Blade (Keywords: Aeroelastic effect; Optimization model; Power loss; Pre-twist angle; Pre-twisting method) [27].

- Energy Model for Long-Term Scenarios in Power Sector under Energy Transition Laws (Keywords: electricity model; power plants prospective; Mexican prospective) [28]. 
- Multi-Agent Consensus Algorithm-Based Optimal Power Dispatch for Islanded Multi-Microgrids (Keywords: islanded multi-microgrids; real-time power dispatch; multi-agent; consensus algorithm) [29].

- Simulation-Based Design and Economic Evaluation of a Novel Internally Circulating Fluidized Bed Reactor for Power Production with Integrated $\mathrm{CO}_{2}$ Capture (Keywords: chemical looping combustion; power production; carbon capture; internally circulating reactor; reactor design; fluidization; techno-economics; computational fluid dynamics; filtered two-fluid model; coarse-grid simulations) [30].

- A Time-Sequence Simulation Method for Power Units' Monthly Energy-Trade Scheduling with Multiple Energy Sources (Keywords: monthly energy-trade scheduling; time-sequence simulation method; feasibility; fairness; consumption of renewable energy) [31].

- Reliability Evaluation Method Considering Demand Response (DR) of Household Electrical Equipment in Distribution Networks (Keywords: demand response; household electrical equipment; real-time electricity price; incentive mechanism; capacity constraint; reliability evaluation) [32].

- A Dispatching Optimization Model for Park Power Supply Systems Considering Power-To-Gas and Peak Regulation Compensation (Keywords: park power supply system; power-to-gas; peak regulation compensation; ancillary service; wind/photovoltaic generation consumption) [33].

- Salp Swarm Optimization Algorithm-Based Controller for Dynamic Response and Power Quality Enhancement of an Islanded Microgrid (Keywords: microgrid; optimization; voltage and frequency regulation; dynamic response enhancement; salp swarm optimization algorithm; power quality) [34].

- Off-Grid Solar PV Power Generation System in Sindh, Pakistan: A Techno-Economic Feasibility Analysis (Keywords: off-grid Solar PV power generation; remote rural regions; economic feasibility; $\mathrm{CO}_{2}$ mitigation; Pakistan) [35].

Research in the industrial production sector and its associated processes have found space in the following works:

- A Novel Robust Method for Solving CMB Receptor Model Based on Enhanced Sampling Monte Carlo Simulation (Keywords: CMB receptor model; effective variance weighted least squares algorithm; enhanced sampling Monte Carlo simulation) [36].

- Mold Level Predictor of Continuous Casting Using Hybrid EMD-SVR-GA Algorithm (Keywords: empirical mode decomposition; support vector regression; genetic algorithm; mold level; continuous cast) [37].

- Artificial Neural Networks Approach for a Multi-Objective Cavitation Optimization Design in a Double-Suction Centrifugal Pump (Keywords: multi-objective optimization; artificial neural network; NPSHr prediction; cavitation optimization; CFD) [38].

- Determination of Acidity of Waste Cooking Oils by Near-Infrared Spectroscopy (Keywords: free acidity; NIRS; partial least squares; waste cooking oil) [39].

- Extended State Observer-Based Predictive Speed Control for Permanent Magnet Linear Synchronous Motor (Keywords: permanent magnet linear synchronous motor (PMLSM); extended state observer (ESO); predictive function control (PFC); composite control; robustness) [40].

- Direct Speed Control of Pmsm Based on Terminal Sliding Mode and Finite Time Observer (Keywords: non-singular terminal sliding mode control (NTSMC); finite-time observer (FTO); mismatched/matched disturbance/uncertainties; permanent magnet synchronous motor (PMSM)) [41].

- Numerical and Experimental Study of a Vortex Structure and Energy Loss in a Novel Self-Priming Pump (Keywords: vortex structure; energy loss; entropy production; self-priming pump) [42]. 
These studies, and the researchers who participated in them are the cornerstone for human well-being of tomorrow, supporting economic development and reducing fuel poverty. The future will be sustainable because it can only be such. The sustainable future is closer than we can imagine.

I must congratulate the authors and reviewers for their outstanding work, and thank the editors, assistants, and all the staff of MDPI for the quality of their work.

Conflicts of Interest: The authors declare no conflicts of interest.

\section{References}

1. Shi, K.; Li, D.; Gong, T.; Dong, M.; Gong, F.; Sun, Y. Smart community energy cost optimization taking user comfort level and renewable energy consumption rate into consideration. Processes 2019, 7, 63. [CrossRef]

2. Valdés, H.; Leon, G. Cogeneration process technical viability for an apartment building: Case study in Mexico. Processes 2019, 7, 93. [CrossRef]

3. Ullah, I.; Khitab, Z.; Khan, M.N.; Hussain, S. An efficient energy management in office using bio-inspired energy optimization algorithms. Processes 2019, 7, 142. [CrossRef]

4. Liu, W.; Liu, C.; Lin, Y.; Bai, K.; Ma, L.; Chen, W. Multi-objective optimal scheduling method for a grid-connected redundant residential microgrid. Processes 2019, 7, 296. [CrossRef]

5. Maritz, J. Optimized energy management strategies for campus hybrid PV-diesel systems during utility load shedding events. Processes 2019, 7, 430. [CrossRef]

6. Hafeez, G.; Islam, N.; Ali, A.; Ahmad, S.; Usman, M.; Saleem Alimgeer, K. A Modular Framework for Optimal Load Scheduling under Price-Based Demand Response Scheme in Smart Grid. Processes 2019, 7, 499. [CrossRef]

7. Li, Y.; Chen, X.; Yu, J. A hybrid energy feature extraction approach for ship-radiated noise based on CEEMDAN combined with energy difference and energy entropy. Processes 2019, 7, 69. [CrossRef]

8. Liu, W.; Tang, T.; Su, S.; Yin, J.; Cao, Y.; Wang, C. Energy-efficient train driving strategy with considering the steep downhill segment. Processes 2019, 7, 77. [CrossRef]

9. Mehdi, G.; Zhou, S.; Zhu, Y.; Shah, A.H.; Chand, K. Numerical investigation of SCR mixer design optimization for improved performance. Processes 2019, 7, 168. [CrossRef]

10. Nguyen, T.-T. A rotor-sync signal-based control system of a doubly-fed induction generator in the shaft generation of a ship. Processes 2019, 7, 188. [CrossRef]

11. Guo, H.; Du, S.; Zhao, F.; Cui, Q.; Ren, W. Intelligent energy management for plug-in hybrid electric bus with limited state space. Processes 2019, 7, 672. [CrossRef]

12. Solangi, Y.A.; Tan, Q.; Mirjat, N.H.; Valasai, G.D.; Khan, M.W.A.; Ikram, M. An integrated Delphi-AHP and fuzzy TOPSIS approach toward ranking and selection of renewable energy resources in Pakistan. Processes 2019, 7, 118. [CrossRef]

13. Sharifi, R.; Anvari-Moghaddam, A.; Fathi, S.H.; Vahidinasab, V. A flexible responsive load economic model for industrial demands. Processes 2019, 7, 147. [CrossRef]

14. Zhang, Y.; Zhang, L.; Liu, Y. Implementation of maximum power point tracking based on variable speed forecasting for wind energy systems. Processes 2019, 7, 158. [CrossRef]

15. Zeng, Y.; Tang, L.; Wu, N.; Song, J.; Zhao, Z. Numerical investigation of influence of reservoir heterogeneity on electricity generation performance of enhanced geothermal system. Processes 2019, 7, 202. [CrossRef]

16. Mengal, A.; Mirjat, N.H.; Walasai, G.D.; Khatri, S.A.; Harijan, K.; Uqaili, M.A. Modeling of future electricity generation and emissions assessment for Pakistan. Processes 2019, 7, 212. [CrossRef]

17. Wang, Y.; Sun, Z.; Yan, Z.; Liang, L.; Song, F.; Niu, Z. Power transmission congestion management based on quasi-dynamic thermal rating. Processes 2019, 7, 244. [CrossRef]

18. Xue, S.; Che, Y.; He, W.; Zhao, Y.; Zhang, R. Control strategy of electric heating loads for reducing power shortage in power grid. Processes 2019, 7, 273. [CrossRef]

19. Sun, L.; Li, B.; Li, Y. Productivity models of infill complex structural wells in mixed well patterns. Processes 2019, 7, 324. [CrossRef]

20. Zhao, Y.; Si, X.; Wang, X.; Zhu, R.; Fu, Q.; Zhong, H. The influence and optimization of geometrical parameters on coast-down characteristics of nuclear reactor coolant pumps. Processes 2019, 7, 327. [CrossRef] 
21. Wang, C.-N.; Tsai, T.-T.; Huang, Y.-F. A model for optimizing location selection for biomass energy power plants. Processes 2019, 7, 353. [CrossRef]

22. Ali Kadhem, A.; Abdul Wahab, N.I.; Abdalla, A. Wind energy generation assessment at specific sites in a Peninsula in Malaysia based on reliability indices. Processes 2019, 7, 399. [CrossRef]

23. Gui, N.; Lou, J.; Qiu, Z.; Gui, W. Temporal Feature Selection for Multi-Step Ahead Reheater Temperature Prediction. Processes 2019, 7, 473. [CrossRef]

24. Khan, M.W.A.; Panigrahi, S.K.; Almuniri, K.S.N.; Soomro, M.I.; Mirjat, N.H.; Alqaydi, E.S. Investigating the Dynamic Impact of CO2 Emissions and Economic Growth on Renewable Energy Production: Evidence from FMOLS and DOLS Tests. Processes 2019, 7, 496. [CrossRef]

25. Teng, T.; Wang, Y.; He, X.; Chen, P. Mathematical Modeling and Simulation on the Stimulation Interactions in Coalbed Methane Thermal Recovery. Processes 2019, 7, 526. [CrossRef]

26. Zheng, T.; Dai, Z.; Yao, J.; Yang, Y.; Cao, J. Economic dispatch of multi-energy system considering load replaceability. Processes 2019, 7, 570. [CrossRef]

27. Zhao, Y.; Liao, C.; Qin, Z.; Yang, K. Using PSO algorithm to compensate power loss due to the aeroelastic effect of thewind turbine blade. Processes 2019, 7, 633. [CrossRef]

28. Hernández-Luna, G.; Romero, R.J.; Rodríguez-Martínez, A.; Ponce-Ortega, J.M.; CerezoRomán, J.; Toledo Vázquez, G.D. Energy model for long-term scenarios in power sector under energy transition laws. Processes 2019, 7, 674. [CrossRef]

29. Zhai, X.; Wang, N. Multi-agent consensus algorithm-based optimal power dispatch for islanded multi-microgrids. Processes 2019, 7, 679.

30. Cloete, J.H.; Khan, M.N.; Cloete, S.; Amini, S. Simulation-based design and economic evaluation of a novel internally circulating fluidized bed reactor for power production with integrated $\mathrm{CO}_{2}$ capture. Processes 2019, 7, 723. [CrossRef]

31. Sun, L.; Zhang, Q.; Zhang, N.; Song, Z.; Liu, X.; Li, W. A Time-Sequence Simulation Method for Power Unit's Monthly Energy-Trade Scheduling with Multiple Energy Sources. Processes 2019, 7, 771. [CrossRef]

32. Chen, H.; Tang, J.; Sun, L.; Zhou, J.; Wang, X.; Mao, Y. Reliability evaluation method considering demand response (DR) of household electrical equipment in distribution networks. Processes 2019, 7, 799. [CrossRef]

33. Qin, Y.; Lin, H.; Tan, Z.; Yan, Q.; Li, L.; Yang, S.; De, G.; Ju, L. A Dispatching Optimization Model for Park Power Supply Systems Considering Power-to-Gas and Peak Regulation Compensation. Processes 2019, 7, 813. [CrossRef]

34. Jumani, T.A.; Mustafa, M.; Anjum, W.; Ayub, S. Salp swarm optimization algorithm-based controller for dynamic response and power quality enhancement of an islanded microgrid. Processes 2019, 7, 840. [CrossRef]

35. Xu, L.; Wang, Y.; Solangi, Y.; Zameer, H.; Shah, S. Off-Grid Solar PV Power Generation System in Sindh, Pakistan: A Techno-Economic Feasibility Analysis. Processes 2019, 7, 308. [CrossRef]

36. Hou, W.; Yang, Y.; Wang, Z.; Hou, M.; Wu, Q.; Xie, X. A novel robust method for solving CMB receptor model based on enhanced sampling Monte Carlo simulation. Processes 2019, 7, 169. [CrossRef]

37. Lei, Z.; Su, W. Mold level predict of continuous casting using hybrid EMD-SVR-GA algorithm. Processes 2019, 7, 177. [CrossRef]

38. Wang, W.; Osman, M.; Pei, J.; Gan, X.; Yin, T. Artificial neural networks approach for a multi-objective cavitation optimization design in a double-suction centrifugal pump. Processes 2019, 7, 246. [CrossRef]

39. García Martín, J.F.; López Barrera, M.C.; Torres García, M.; Zhang, Q.-A.; Álvarez Mateos, P. Determination of the acidity of waste cooking oils by near infrared spectroscopy. Processes 2019, 7, 304. [CrossRef]

40. Wang, Y.; Yu, H.; Che, Z.; Wang, Y.; Zeng, C. Extended state observer-based predictive speed control for permanent magnet linear synchronous motor. Processes 2019, 7, 618. [CrossRef]

41. Wang, Y.; Yu, H.; Che, Z.; Wang, Y.; Liu, Y. The direct speed control of PMSM based on terminal sliding mode and finite time observer. Processes 2019, 7, 624. [CrossRef]

42. Chang, H.; Agarwal, R.K.; Li, W.; Zhou, L.; Shi, W. Numerical and experimental study of a vortex structure and energy loss in a novel self-priming pump. Processes 2019, 7, 701. [CrossRef]

(C) 2020 by the authors. Licensee MDPI, Basel, Switzerland. This article is an open access article distributed under the terms and conditions of the Creative Commons Attribution (CC BY) license (http://creativecommons.org/licenses/by/4.0/). 